\title{
Penerapan Model Pembelajaran Numbered Head Together Berbantu Permainan Ular Tangga Untuk Peningkatan Hasil Belajar Siswa
}

\author{
Merna Yunia Artha ${ }^{1}$, Mohammad Kanzunnudin ${ }^{2}$, dan Imaniar Purbasari ${ }^{3}$ \\ 1,2,3Universitas Muria Kudus \\ Email: yuniamerna@gmail.com
}

\begin{tabular}{|c|c|}
\hline Info Artikel & Abstract \\
\hline $\begin{array}{l}\text { Sejarah Artikel: } \\
\text { Diterima 16 Agustus } 2021 \\
\text { Direvisi } 24 \text { Agustus } 2021 . \\
\text { Disetujui } 9 \text { November } 2021\end{array}$ & $\begin{array}{l}\text { The purpose of this study is to describe the improvement of student learning outcomes on } \\
\text { the theme of My Living Area in the fourth grade of SD } 3 \text { Panjang with the application of } \\
\text { the Numbered Head Together (NHT) learning model assisted by Snakes and Ladders } \\
\text { media. } \\
\text { The research method used is classroom action research which was carried out in class IV } \\
\text { SD } 3 \text { Panjang with } 16 \text { students as research subjects which lasted for two cycles, each cycle }\end{array}$ \\
\hline $\begin{array}{l}\text { Keywords: } \\
\text { Social Studies Learning } \\
\text { Outcomes, Numbered Head } \\
\text { Together, Snakes and Ladders. }\end{array}$ & $\begin{array}{l}\text { consisting of two meetings. The dependent variables in this study are the Numbered Head } \\
\text { Together learning model and Snakes and Ladders Game media, while the dependent } \\
\text { variable is student learning outcomes on the Regional Theme I Live in and the teacher's } \\
\text { teaching skills on the Regional Theme where I live. Data collection methods in the form of } \\
\text { tests, observations, interviews, and documentation. The data obtained from the actions } \\
\text { taken were analyzed quantitatively and qualitatively. }\end{array}$ \\
\hline & $\begin{array}{l}\text { The results showed that the use of the Numbered Head Together learning model with the } \\
\text { help of the snake and ladder game could improve student learning outcomes on the theme } \\
\text { of the area where I live, social studies content and Indonesian language for class IV SD } 3 \\
\text { Panjang from an average social studies score of } 37.5 \% \text {, Indonesian language } 43.75 \% \\
\text { before The research was conducted to find the average score for social studies was } 62.5 \% \text {, } \\
\text { Indonesian language was } 56.3 \% \text { in the first cycle and improved even more in the second } \\
\text { cycle with an average social studies score of } 81.25 \% \text {, Indonesian } 75 \% \text { from the KKM } 70 \text {. }\end{array}$ \\
\hline
\end{tabular}

\begin{abstract}
Abstrak
Tujuan penelitian ini yaitu mendeskripsikan peningkatan hasil belajar siswa pada tema Daerah Tempat Tinggalku kelas IV SD 3 Panjang dengan penerapan model pembelajaran Numbered Head Together (NHT) berbantuan media Ular Tangga.

Metode penelitian yang digunakan yaitu penelitian tindakan kelas yang dilaksanakan di kelas IV SD 3 Panjang dengan subjek penelitian 16 siswa yang berlangsung selama dua siklus masing-masing siklus terdiri dari dua pertemuan. Variabel bebas dalam penelitian ini yakni model pembelajaran Numbered Head Together dan media Permainan Ular Tangga, sedangkan variabel terikatnya yaitu hasil belajar siswa pada Tema Daerah Tempat Tinggalku dan keterampilan mengajar guru pada Tema Daerah Tempat Tinggalku. Metode pengumpulan data berupa tes, observasi, wawancara, dan dokumentasi. Data yang diperoleh dari tindakan yang dilakukan dianalisis secara kuantitatif dan kualitatif. Hasil penelitian menunjukkan Penggunaan model pembelajaran Numbered Head Together berbantu permainan ular tangga dapat meningkatkan hasil belajar siswa pada Tema daerah Tempat Tinggalku muatan IPS dan Bahasa Indonesia kelas IV SD 3 Panjangdari nilai ratarata IPS $37,5 \%$, Bahasa Indonesia $43,75 \%$ sebelum diadakan penelitian menjadi nilai ratarata IPS $62,5 \%$, Bahasa Indonesia $56,3 \%$ pada siklus I dan meningkat lebih baik lagi pada siklus II dengan nilai rata-rata IPS $81,25 \%$, Bahasa Indonesia $75 \%$ dari KKM 70.
\end{abstract}

(C) 2021 Universitas Muria Kudus 


\section{PENDAHULUAN}

Belajar merupakan aktivitas yang dilakukan seseorang untuk mendapatkan perubahan dalam dirinya melalui pelatihanpelatihan atau pengalaman-pengalaman (Baharuddin 2008). Hasil belajar adalah perwujudan kemampuan akibat perubahan perilaku yang dilakukan oleh usaha pendidikan. Dalam usaha memudahkan memahami dan mengukur perubahan perilaku maka perilaku kejiwaan manusia dibagi menjadi tiga domain atau ranah: kognitif; afektif; dan psikomotorik (Purwanto 2013).

Hasil wawancara dengan guru kelas IV SD 3 Panjang Suci Anggraeni S.Pd.SD yang dilakukan pada 1 Oktober 2018, diperoleh informasi permasalahan yang dihadapi guru dalam melaksanakan kegiatan belajar mengajar yang menyebabkan rendahnya hasil belajar siswa. Pembelajaran tersebut berdampak pada rendahnya pencapaian hasil belajar siswa. Berdasarkan hasil ulangan harian kelas IV SD 3 Panjang pada tahun ajaran 2018/2019, dalam pelajaran Ilmu Pengetahuan Sosial pada materi kenampakan alam dan buatan, ada 10 siswa dari total 16 siswa atau sebesar $62,5 \%$ siswa yang nilainya masih di bawah KKM yakni 70 . Dalam pelajaran Bahasa Indonesia pada materi laporan hasil pengamatan ada 9 siswa dari total 16 siswa atau sebesar $56,25 \%$ yang nilainya masih di bawah KKM yaitu 70. Rendahnya hasil belajar disebabkan pembelajaran berpusat pada guru dan siswa kurang aktif berfikir sehingga kurang memahami materi yang dipelajari yang pada akhirnya berdampak pada rendahnya hasil belajar.

Berbagai upaya telah dilakukan oleh guru untuk membuat siswa menjadi aktif, salah satunya dengan melakukan kegiatan pembelajaran secara berkelompok. Hasil wawancara dengan siswa kelas IV SD 3 Panjang yang dilakukan pada 1 Oktober 2018, terdapat beberapa permasalahan yang dialami siwa. Beberapa siswa tidak dapat menerima materi yang diajarkan guru dengan baik. Siswa kurang berminat dalam mengikuti pembelajaran, karena dalam proses pembelajaran siswa hanya aktif mendengarkan penjelasan materi dari guru.

Kondisi pembelajaran tersebut menyebabkan rendahnya pencapaian hasil belajar siswa. Hal ini dapat terjadi karena pembelajaran masih didominasi oleh guru atau pembelajaran yang dilakukan masih menggunakan metode ceramah. Guru pada saat ini belum menciptakan pembelajaran yang kreatif dengan berbagai alasan seperti, belum mempunyai ide karena kesibukan yang dijalaninya. Oleh karena itu, guru belum berhasil dalam meningkatkan hasil belajar siswa.

Berdasarkan permasalahan tersebut, solusi untuk meningkatkan hasil belajar siswa melalui pembelajaran dengan menerapkan model pembelajaran Cooperative Learning tipe Numbered Head Together. Model pembelajaran Numbered Head Together merupakan salah satu dari strategi pembelajaran kooperatif

Peningkatan hasil belajar siswa dengan penerapan model pembelajaran Numbered Head Togetherdapat diperkuat dengan penelitian yang dilakukan Mana'a, Saneba \& Panimbong (2015) menunjukan bahwa hasil belajar siswa dapat dilihat dari daya serap, ketuntasan, dan post tes siswa sebagai berikut: a) daya serap siswa pada siklus I memperoleh nilai rata-rata 66,29 meningkat pada siklus II menjadi 81,95 ; b) ketuntasan siswa pada siklus I dengan hasil tidak tuntas meningkat pada siklus II dengan hasil yang tuntas; c) post test yang diperoleh siswa pada siklus I memperoleh nilai 68,45 meningkat pada siklus II dengan nilai rata-rata 85,87 .

Trianto (2009: 82) menyatakan bahwa pembelajaran kooperatif tipe Numbered Head Together(NHT) atau penomoran berpikir bersama, "Merupakan jenis pembelajaran kooperatif yang dirancang untuk mempengaruhi pola interaksi siswa dan sebagai alternative terhadap struktur kelas tradisional”.

Alasan menggunakan model pembelajaran Numbered Head Togetherkarena sesuai dengan karakteristik siswa pada SD 3 Panjang. Model pembelajaran Numbered Head Togetherdapat memberi kesempatan pada siswa untuk saling berbagi gagasan dan mempertimbangkan jawabannya serta meningkatkan kerjasama antar anggota kelompok. Berdasarkan uraian latar belakang di atas, tujuan riset ini yaitu mendeskripsikan penerapan model pembelajaran Numbered Head Together berbantu permainan ular tangga dalam meningkatkan hasil belajar siswa tema Daerah Tempat Tinggalku kelas IV SD 3 Panjang

\section{METODE PENELITIAN}

Lokasi penelitian tindakan kelas ini dilakukan di SD 3 Panjang, yang beralamatkan di Jalan Lingkar Utara Panjang RT 02 RW 03 Desa Panjang, Kecamatan Bae, Kabupaten Kudus. Penelitian dilakukan mulai Oktober 2018 sampai Januari 2019.

Jenis Penelitian ini yaitu Penelitian Tindakan Kelas. Subjek penelitian yaitu siswa kelas IV SD 3 Panjang Kecamatan Bae, Kabupaten Kudus, yang berjumlah 16 siswa terdiri dari 9 siswa berjenis kelamin laki-laki dan 
7 siswa berjenis kelamin perempuan. Pada penelitian ini, variabel bebasnya adalah model pembelajaran Numbered Head Together dan media ular tangga.

Penelitian ini dilaksanakan dua siklus dan masing-masing siklus meliputi perencanaan, tindakan, pengamatan, dan refleksi. Teknik pengumpulan data dilakukan dengan: (1) wawancara, (2) observasi, (3) tes, (4) dokumentasi. Sumber data primer siswa diperoleh dari hasil wawancara dengan siswa kelas IV SD 3 Panjang. Observasi dan dokumentasi dilakukan selama pelaksanaan pembelajaran siklus I dan siklus II.

Sumber data sekunder dokumentasi berupa referensi buku, jurnal penelitian, foto, daftar siswa kelas IV dan nilai awal dari hasil tes yang berupa nilai ulangan tengah semester yang telah dilaksanakan oleh siswa kelas IV SD 3 Panjang.

Wawancara yang digunakan peneliti adalah wawancara tidak terstruktur. Tujuan wawancara dalam penelitian ini yakni untuk mengetahui respon atau tanggapan siswa sebelum dan sesudah diterapkannya model Numbered Head Together. Observasi ini digunakan untuk mengamati proses pembelajaran yang dilakukan oleh siswa kelas IV maupun pada saat dilakukannya penelitian tindakan kelas.

Dokumentasi dalam penelitian ini bertujuan untuk mengumpulkan data dan mengetahui data peserta didik kelas IV, proses kegiatan pembelajaran Number Head Together. Dalam pelaksanaan metode dokumentasi ini, peneliti menggunakan dokumentasi foto untuk mengumpulkan data pengambilan dokumen foto ini meliputi kegiatan awal, inti, dan penutup.

Instrumen penelitian yang digunakan dalam penelitian yaitu pedoman observasi hasil belajar siswa aspek keterampilan. Validitas dari sebuah instrumen dapat diketahui dengan menghitung korelasi antara nilai hasil uji coba. Korelasi ini dihitung menggunakan rumus Product Moment dengan angka kasar.

Uji validitas soal siklus I dan siklus II diuji cobakan pada siswa kelas IV SD 3 Panjang jumlah siswa sebanyak 16 siswa. Soal tes uji coba sebanyak 30 butir soal untuk siklus I dan II.

Pada siklus I terdapat sebanyak 30 soal pilihan ganda untuk diuji coba. Hasil analisis validitas soal siklus I dari 30 soal yang diuji cobakan yang valid sebanyak 21 soal dan 9 soal tidak valid.

Adapun soal yang dipakai dalam evaluasi akhir sebanyak 20 butir. Hal tersebut dikarenakan 20 soal tersebut telah memenuhi semua indikator pembelajaran, maka soal yang digunakan yaitu soal nomor $2,3,4,5,8,9,10,13,14,15,16,17,18,19,20,21,22,26$, 28 , dan 29. Sehingga terdapat 1 soal yang tidak digunakan dalam soal evaluasi siklus I yaitu nomer soal 24 karena indikator yang ada sudah terwakili oleh 20 soal tersebut. Dan soal yang tidak valid diantaranya terdiri dari nomor 1,6,7,11,12,23,25,27,30. Kemudian untuk mengukur sejauh mana perolehan hasil belajar aspek pengetahuan siswa dari 20 soal yang valid digunakan sebagai tes hasil belajar.

Siklus II terdapat 30 soal pilihan ganda yang diuji cobakan. Hasil analisis validitas soal siklus II dari 30 soal yang diuji cobakan soal yang valid sebanyak 22 dan 8 soal tidak valid.

Adapun soal yang dipakai dalam evaluasi akhir sebanyak 20 butir. Hal tersebut dikarenakan soal 20 tersebut telah memenuhi semua indikator pembelajaran, maka soal yang digunakan yakni soal nomor $1,2,3,4,5,6,7,9,10,11,12,13,14,15,19,21,22,23,25$, 27. Sehingga terdapat 2 soal yang tidak digunakan dalam soal evaluasi akhir siklus II yaitu nomor soal 28, dan 30 karena indikator yang ada sudah terwakili oleh soal 20 tersebut. Kemudian soal yang tidak valid terdiri dari nomor 8,16,17,18,20,24,26,29. Untuk melakukan evaluasi pada siklus II diambil 20 soal yang valid sebagai hasil belajar aspek pengetahuan siswa. Uraian di atas dapat disimpulkan bahwa soal tes akhir siklus I dan siklus II layak dijadikan sebagai soal evaluasi.

Analisis data dalam penelitian ini menggunakan analisis data kuantitatif dan analisis data kualitatif untuk memastikan bahwa hasil belajar siswa kelas IV SD 3 Panjang pada pembelajaran tematik tema Daerah Tempat Tinggalku meningkat dengan penerapan model pembelajaram Numbered Head Together berbantu permainan ular tangga.

\section{HASIL DAN PEMBAHASAN}

Seseorang yang mau belajar akan mendapatkan hasil yang maksimal seperti siswa yang pada awalnya mau belajar dengan tekun pasti mendapatkan hasil yang memuaskan. Susanto (2013) menjelaskan bahwasannya hasil belajar adalah perubahan-perubahan yang terjadi pada diri siswa, baik yang menyangkut aspek kognitif, afektif, dan psikomotor sebagai hasil dari kegiatan belajar. Oleh sebab itu, ketiga aspek tersebut harus dipandang sebagai hasil belajar siswa dari proses pengajaran. Gestalt (Susanto 2013) berpendapat bahwa hasil belajar siswa dipengaruhi oleh dua hal, siswa itu sendiri dan lingkungannya. 
Hasil belajar pada penelitian ini diperoleh dari muatan IPS dan Bahasa indonesia pada Tema Daerah Tempat Tinggalku melalui penerapan model pembelajaran Numbered Head Together Berbantu Permainan Ular Tangga. Sudjana (2012) mengemukakan bahwa hasil belajar adalah kemampuan-kemampuan yang dimiliki siswa setelah ia menerima pengalaman belajarnya.

Penilaian kompetensi pengetahuan diukur melalui tes evaluasi berupa soal pilihan ganda. Penilaian kompetensi keterampilan diukur melalui penilaian kinerja dengan instrumen lembar kinerja siswa. Setelah melakukan penelitian tindakan kelas selama dua siklus dengan menerapkan model pembelajaran Numbered Head Together Berbantu Permainan Ular Tangga pada Tema Daerah Tempat Tinggalku muatan IPS dan Bahasa Indonesia siswa kelas IV SD 03 Panjang, maka hasil belajar aspek pengetahuan dan aspek keterampilan siswa sebagai berikut.

\section{Hasil Belajar Aspek Pengetahuan Melalui \\ Model Numbered Head Together \\ Berbantu Permainan Ular Tangga.}

Hasil belajar aspek pengetahuan meliputi pengetahuan/ingatan/hafalan (C1), pemahaman (C2), penerapan (C3), analisis (C4), evaluasi (C5), dan mencipta (C6) yang dijelaskan Bloom dalam (Purwanto, 2013). Kemudian Nurgiyantoro (2014) menejlaskan bahwa aspek pengetahuan berkaitan dengan kemampuan intelektual dan kompetensi berpikir seseorang.

Hasil penelitian pada aspek pengetahuan siswa kelas IV SD 03 Panjang telah mengalami peningkatan. Muatan IPS pada Prasiklus memperoleh persentase sebesar 37,5\% dengan kualifikasi sangat kurang. Kemudian meningkat pada Siklus I memperoleh persentase sebesar $62,5 \%$ dengan kualifikasi kurang. Sedangkan pada muatan Bahasa Indonesia Prasiklus memperoleh persentase sebesar $43,75 \%$ dengan kualifikasi sangat kurang. Dan meningkat pada Siklus I memperoleh persentase sebesar 56,3\% dengan kualifikasi sangat kurang. Hal ini belum menunjukkaan indikator keberhasilan dikarenakan ketuntasan klasikal yang ditetapkan yaitu minimal $\geq 70 \%$, sehingga perlu dioptimalkan lagi pada siklus II guna melakukan perbaikan.

Hasil belajar yang diperoleh siswa tidak terlepas permasalahan dalam menerapkan model pembelajaran Numbered Head Togetherberbantu permainan ular tangga pada siklus I. Ada banyak faktor yang mempengaruhi terjadinya permasalahan dalam belajar yang mengakibatkan hasil belajar siswa kurang maksimal. Susanto
(2013) mengemukakan bahwa faktor-faktor yang mempengaruhi hasil belajar terdapat duamacam, yakni faktor internal dan faktor eksternal. Faktor internal yaitu faktor yang berasal dari dalam diri siswa yang mempengaruhi hasil belajarnya, meliputi kecerdasan, minat, dan perhatian, motivasi belajar, ketekunan, sikap kebiasaan belajar, serta kondisi fisik dan kesehatan. Faktor eksternal yaitu faktor yang berasal dari luar diri siswa yang mempengaruhi hasil belajarnya, meliputi keluarga, sekolah, dan masyarakat.

Permasalahan dalam menerapkan model pembelajaran Numbered Head Together berbantu permainan ular tangga yang mengakibatkan masih rendahnya hasil belajar siswa adalah siswa belum berani bertanya dan mengemukakan pendapatnya. Munculnya permasalahan pada siklus I memberikan masukan untuk melakukan perbaikan pada siklus II. Solusi untuk mengatasi permasalahan tersebut yakni memberikan motivasi kepada siswa secara lebih mendalam agar siswa dapat bertanya dan menguatarakan pendapatnya dengan percaya diri.

Guru melakukan upaya perbaikanperbaikan pembelajaran pada siklus II setelah menganalisis kekurangan-kekurangan dalam pembelajaran pada silus I. Adapun hasil belajar siswa pada siklus II persentase ketuntasan siswa pada muatan IPS mencapai $81,25 \%$ dalam kategori baik, sedangkan muatan Bahasa Indonesia mencapai persentase ketuntasan siswa sebesar $75 \%$ dalam kategori baik. Hal tersebut menunjukkan bahwa adanya peningkatan ketuntasan siswa pada siklus I ke siklus II mencapai $18,75 \%$ pada muatan IPS, sedangkan muatan Bahasa Indonesia meningkat mencapai $18,7 \%$. Hal tersebut telah mencapai indikator keberhasilan yang ditentukan minimal mencapai $\geq 70 \%$ dengan kategori baik. Dengan demikian bahwa mata pelajaran IPS dan Bahasa Indonesia materi Kegiatan Ekonomi (Produksi, Konsumsi, dan Distribusi), Jenis-Jenis Pekerjaan (Dataran Tinggi dan Rendah), dan Cerita Fiksi dengan menerapkan model pembelajaran Numbered Head Togetherdapat meningkatkan hasil belajar siswa kelas IV SD 03 Panjang.Faktor-faktor yang mempengaruhi hasil belajar siswa sehingga dapat teratasi dengan penerapan model pembelajaran Numbered Head Together. Hal ini sejalan dengan Jamilah, Gandhi \& Sadiqin (2017) menyatakan bahwa pembelajarran menggunakan model Numbered Head Together dikatakan dapat meningkatkan hasil belajar siswa.

Muatan IPS pada Siklus II terdapat 3 siswa yang belum tuntas, Sedangkan siswa yang tuntas terdapat 13 siswa, bahkan terdapat 1 siswa yang mendapatkan nilai 100 , yang sebelumnya 
pada siklus I hanya terdapat 10 siswa tuntas dan terdapat 6 siswa yang tidak tuntas. Sedangkan pada muatan Bahasa Indonesia pada siklus II terdapat 4 siswa yang belum tuntas, Sedangkan siswa yang tuntas terdapat 12 siswa, Bahkan terdapat 1 siswa yang mendapatkan nilai 100 , dari sebelumnya pada siklus I hanya terdapat 9 siswa tuntas dan 7 siswa belum tuntas. Sama halnya menurut Bloom (Purwanto 2013) menjelaskan bahwa tingkat hasil belajar kognitif (pengetahuan) mulai dari yang paling rendah sampai yang paling tinngi.

Berdasarkan uraian di atas maka dapat disimpulkan bahwa terdapat peningkatan hasil belajar siswa kelas IV SD 3 Panjang pada tema Daerah Tempat Tinggalku muatan IPS dan Bahasa Indonesia melalui model pembelajaran Contextual Teaching Learning berbantu permainan ular tangga. Peningkatan hasil belajar dapat dilihat dari nilai prasiklus, siklus I sampai hasil belajar siklus II.

\section{Hasil Belajar Keterampilan Siswa Melalui Model Numbered Head TogetherBerbantu Permainan Ular Tangga.}

Hasil belajar aspek keterampilan pada penelitian ini melalui model pembelajaran Numbered Head Together berbantu permainan ular tangga pada tema daerah Tempat Tinggalku muatan IPS dan Bahasa Indonesia mengalami peningkatan dari siklus I ke siklus II. Susanto (2013) mengemukakan bahwa keterampilan proses merupakan keterampilan yang mengarahkan pada pembangunan kemampuan mental, fiaik, dan sosial yang mendasar sebagai penggerak kemampuan yang lebih tinggi dalam diri individu siswa. Keterampilan berarti kemampuan menggunakan pikiran, nalar dan perbuatan secara efektif dan efisien untuk mencapai suatu hasil tertentu termasuk kreativitasnya.

Peningkatan keterampilan siswa muatan IPS dan Bahasa Indonesia pada tema daerah Tempat Tinggalku dengan menerapkan model Numbered Head Together berbantu permainan ular tangga telah terjadi dari siklus I sampai siklus II. Hasil belajar aspek keterampilan muatan IPS pada siklus I memperoleh rata-rata persentase $67,94 \%$ kemudian meningkat pada siklus II menjadi $88,75 \%$. Hasil belajar aspek keterampilan muatan Bahasa indonesia pada siklus I memperoleh rata-rata persentase $70,51 \%$ kemudian meningkat pada siklus II menjadi $89,42 \%$. Hal ini sejalan dengan penelitian Yuliantiningtiyas (2015) menyatakan bahwa peningkatan hasil belajar ranah keterampilan siswa dalam pembelajaran yang terbukti dengan peningkatan siklus I ke siklus I di kelas IV pada SD 6 Gugus Moch Hatta.

Pada siklus I siswa masih beradaptasi dengan model pembelajaran Numbered Head Together. Hasil pengamatan menunjukkan bahwa dalam mengikuti pembelajaran siswa masih suka gaduh. Selain itu siswa dalam berdiskusi belum ada rasa tanggung jawab dan kerjasama dengan baik. Hal ini sejalan dengan Kula (2013) dengan menggunakan model Numbered Head Together cara ini juga merupakan usaha yag sangat baik untuk meningkatkan tanggung jawab individual dalam diskusi kelompok.

Hal yang dapat meningkatkan keterampilan siswa yaitu keterampilan bekerjasama kelompok dalam menyelesaikan soal pada permainan ular tangga dan keterampilan berbicara mengemukakan pendapat. Upaya pada Siklus II pemberian motivasi, penguatan dan juga memberikan aturan bahwa dalam menulis dan menjawab pertanyaan dari soal harus bergantian, semua harus mendapatkan bagian, dan bagi siswa yang tidak mau bekerjasama dalam kelompok harap di tulis namanya kemudian nama tersebut diserahkan, sehingga dengan begitu siswa merasa takut. Siswa juga diberi kesempatan lebih untuk mengemukakan pendapatnya dengan cara memberi beberapa pertanyaan.

Berdasarkan uraian di atas, penelitian di kelas IV SD 03 Panjang menggunakan model Numbered Head Together berbantu permainan ular tangga pada tema daerah Tempat Tinggalku muatan IPS dan Bahasa Indonesiamengalami peningkatan. Rata-rata nilai persentase aspek keterampilan muatan IPS pada siklus II mencapai $88,78 \%$ kriteria baik. Sedangkan muatan Bahasa Indonesia pada siklus II mencapai $89,42 \%$ kriteria baik. Hasil tersebut telah memenuhi indikator keberhasilan yang ditentukan, yakni minimal mencapai $\geq 70 \%$ dengan kategori baik.

\section{SIMPULAN}

Berdasarkan hasil penelitian tindakan kelas yang telah dilakukan pada pembelajaran tematik Tema Daerah Tempat Tinggalku muatan IPS dan Bahasa Indonesia dengan menerapkan model pembelajaran Numbered Head Together berbantu permainan ular tangga pada siswa kelas IV SD 3 Panjang dapat ditarik simpulan bahwa hasil belajar siswa aspek pengetahuan muatan IPS dan Bahasa Indonesia melalui model Numbered Head Together berbantu permainan ular tangga mengalami peningkatan yang cukup signifikan, pada siklus I muatan IPS memperoleh persentase sebesar $62,50 \%$ dengan kualifikasi kurangdan 
muatan siklus II memperoleh persentase sebesar $81,25 \%$ dengan kualifikasi baik. Sedangkan pada muatan Bahasa Indonesia siklus I memperoleh persentase sebesar 56,30\% dengan kualifikasi cukup, dan pada siklus II muatan Bahasa Indonseia meningkat memperoleh persentase sebesar 75\% dengan kualifikasi baik.

Hasil tersebut telah memenuhi indikator keberhasilan yang ditentukan, yakni sesuai kriteria ketuntasan minimal mencapai $\geq 70 \%$ dengan kategori baik.

\section{DAFTAR PUSTAKA}

Afandi, R. (2015). Pengembangan Media Pembelajaran Permainan Ular Tangga Untuk Meningkatkan Motivasi Belajar Siswa dan Hasil Belajar IPS di Sekolah Dasar. JINoP (Jurnal Inovasi Pembelajaran), $\quad 1 \quad$ (1), 77-89. https://doi.org/10.22219/jinop.v1i1.2450

Aqib, (2014). Penelitian Tindakan Kelas. Bandung: CV YRAMA WIDYA.

Arikunto, Suharsimi. (2010). Prosedur Penelitian Suatu Pendekatan Praktik. Jakarta: PT Rineka Cipta.

Arikunto, Suharsimi., dkk. (2012). Penelitian Tindakan Kelas. Jakarta: PT Bumi Aksara.

Ginting, Kula. (2013). penerapan Model Pembelajaran Contextual Teaching And Learning Untuk Meningkatkan Aktivitas Dan Hasil Belajar IPS Siswa Kelas V SD Negeri 060885 Medan. Skripsi. Medan: Universitas Negeri Medan.

Jamilah, Gandhi, Mahutma \& Sadiqin, Ikhwan Khairu. (2020). Kompetensi Guru Sd Di Banjarmasin Dalam Merancang Perangkat Penilaian Tematik. MUALLIMUNA : JURNAL MADRASAH IBTIDAIYAH, 5 (2), 66-73.

Kunandar. (2014). Penilaian Autentik. Jakarta: PT Raja Grafindo Persada.

Mana'a, Sriwinda., Saneba, Bonifasius \& Palimbong, Anthonius. (2015). Meningkatkan Hasil Belajar Siswa Pada Pembelajaran IPS Dengan Menggunakan Pembelajaran Koperatif Tipe Numbered Heads Together di Kelas IV SDN Lalong Kecamatan Tinangkung Utara Kabupaten
Banggai Kepulauan. Jurnal Kreatif Tadulako Online, 3 (3).

Nurgiyantoro, Burhan. (2014). Penilaian Pembelajaran Bahasa. Yogyakarta: BPFE-YOGYAKARTA.

Purwanto. (2013). Evaluasi Hasil Belajar. Yogyakarta: Pustaka Belajar.

Rahmawati, A., Ismaya, E., \& Roysa, M. (2020). Implementasi Model Pembelajaran Numbered Head Together Berbantuan Media Roda Putar untuk Meningkatkan Hasil Belajar Siswa. Journal on Education, 2(4), 283-296. https://doi.org/10.31004/joe.v2i4.321

Sanjaya, Wina. (2008). Strategi Pembelajaran Berorientasi Standar Proses Pendidikan. Jakarta: Prenada Media Group.

Shoimin, Aris. (2014). 68 Model Pembelajaran Inovatif dalam Kurikulum 2013. Yogyakarta: Ar-ruzz Media.

Sudjana, Nana. (2011). Penilaian Hasil Proses Belajar Mengajar. Bandung: PT Remaja Rosdakarya.

Sugiyono. 2010. Metode Penelitian Pendidikan Pendekatan Kuantitatif, Kualitatif dan $R \& D$. Bandung: Alfabeta.

Susanto, Ahmad. (2013). Teori Belajar dan Pembelajaran di Sekolah Dasar. Jakarta: Kencana.

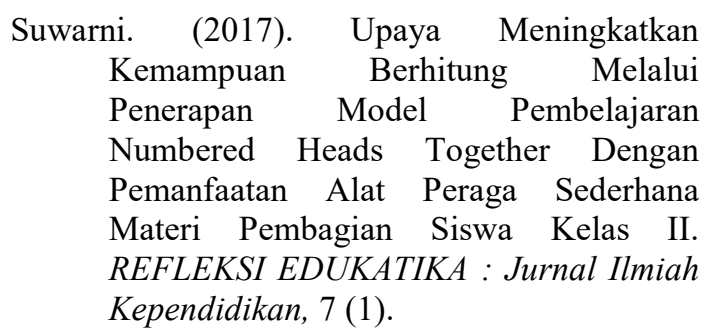

